\title{
（17）金属疲労の微視的研究 (第1報)
}

\author{
大阪大学荒田吉明古市博
}

\section{1. 緒 言}

周知のごとく, 疲労き裂の発生, 伝播に関してその微 視的機構を解明することは, 溶接部などの疲労破壊に対 して基本的に重要な問題である.

疲労き裂発生に関する説としては，（1）交叉すべり によるむの，(2) 交叉すべり以外のすべりによるもの, および, (3) 疲労過程中に試験片表面に生じるピット列 によるあのがある.

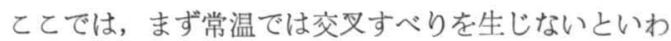
れている亜鉛を用い，疲労過程中で試験片表面および内 部にあらわれる種々の微視的現象についての観測結果に ついて報告する。

\section{2. 実験方法}

室温大気中において, 応力繰返し速度 660 c.p.m. で, 回転曲げにより疲労試験を行ない, 疲労過程中で試験片 表面および内部を光学顕微鏡, 電子顕微鏡で観察を行な った。

なお応力は試験片つかみ部近くで, $\pm 2 \mathrm{~kg} / \mathrm{mm}^{2}$ であ る. (Fig. 1)

\section{3 . 実験結果}

疲労過程中に大きな粒界移動を生じ, この移動跡に, 元の粒界にほぼ平行なピット列が存在し，凹みをなして いるものがあることを認めて報告してきたが，ここでは さらに，(1) 粒界の移動跡を化学研磨した結果, 食われ てゆく結晶内の移動した粒界の付近に多くのピットが群 がって生じる場合のあることが認められた。 (Photo.1)

(2) 疲労過程中に突き出しおよび入り込みの発生する ことが認められた。 (Photo. 2)（3）試験片表面に，粒 界付近のすべり線に浴ってほぼ平行な細長島状の模様が 認められるとともに，ピットで囲まれた丸い模様が元の 粒界に対して，粒界移動方向之は逆の側に認められた。 (Photo. 3, Photo. 4) (4) 元の粒界にほぼ平行なピッ ト列ばかりでなく, すべり線に沿うピット列も認められ た. (Photo. 5) などの結果が見出されたので，これら に対して報告をする。

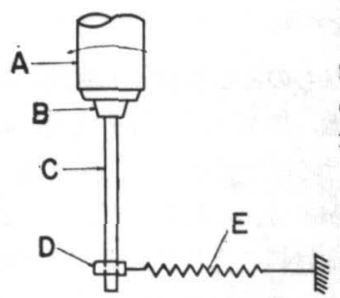

Fig. 1

Schematic reprrsentation of the apparatous for fatigue test

A : rotating shaft

B : specimen holder

C : specimen $\mathrm{D}$ : bearing $\mathrm{E}$ : spring

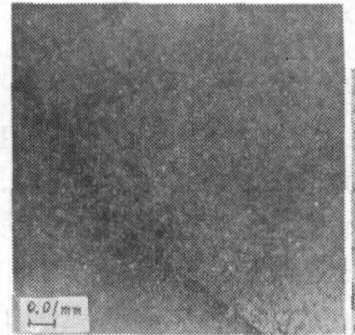

Photo. 1 Pits appeared after polishing chemically the sursace of the fatigued specimen. $3 \times 10^{5}$ cycles

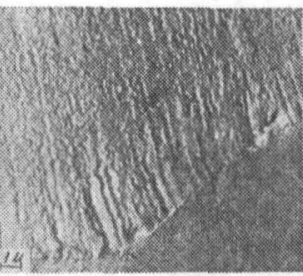

Rhoto. 2 Extrusions and intrusions. $3 \times 10^{5}$ cycles

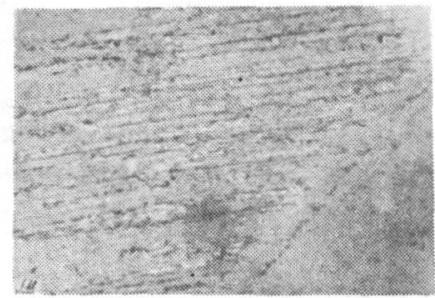

Photo. 3 Island-like patterns. $2 \times 10^{5}$ cycles

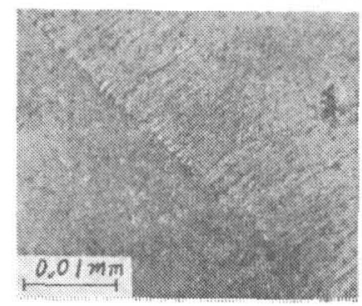

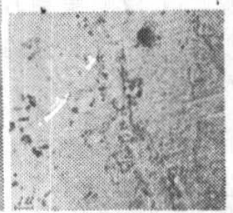

Photo. 4 Round patterns encircled by pits. $3 \times 10^{5}$ cycles
Photo. 5 Rows of pits running along slip lines. $2 \times 10^{5}$ cycles 


\title{
（18）軟鋼一銅材の疲れ強さについて
}

\author{
名古屋大学工学部 益本 功 玉 置 維 昭
}

\section{1.緒言}

一般に金属材料忧均質なものとして設計上取扱われて いるが，実際には圧延組織，加工法似よる性変形の不 均一あるいは溶接部に㧍ける熱影響による局部的性質変 化など，均質でない場合が多数知られている。また耐食 性向上のために故意に異種材料を合わせたクラッド材む ある.そてで棈造用材料を各種の異種材料を組合わせて 作れば，従来の材料とは異なった性質のものが得られる ことが考えられる.しかしこのような複合材料の譏械的 諸性質についてはほとんど检討されていない。

著者らは波れ破壊加常に切欠部の表面加ら発生し, 瘦 れきれつには微少のすべりが先行するととに着目して， すでに軟鎆溶接継手の疲れ強さに扔上ぼす亜鉛メッキの 効果について報告した．本研究では疲れ破壊のように表 面の性質がきわめて重要な場合に，表面と内部が異なる 材料ではどのような変化が起るかをしらべた。すなわち 実験としてはまず鋼の表面に他の金属を重ねた複合材料 を作り，その機械的性質をしらべた。，上くに本報では切 欠底にあたる部分にそ性変形しやすい銅を接合した試験 片により疲労試験を行なった。

\section{2. 実験方法}

素材として軟鋼棒および純銅管を用い，乙れらをFig. 1 のように接合した。すなわち $9.6 \mathrm{~mm} \phi$ の軟鎡棒を内 径 $10 \mathrm{~mm}$ の銅管中にそう入して, 両者をエポキシ系樹 脂で接着し， $80^{\circ}$ に 1 時間加熱して硬化させた。接着後 試験片に各種の深さの円周 $\mathrm{V}$ 型切欠をつけた。疲労試験 は能力 $10 \mathrm{~kg}-\mathrm{m}$, 回転数 3000 回/分 の小野式回転曲げ疲 労試験機によった。また試験片にかかる最大応力は切欠 部の全直径 (Fig. 1 にdで示す) 加ら算出した。

\section{3．実験結果}

Fig. 1 は切欠つき試験片の S-N 線図であって，切欠 底部における銅層の厚さ $\mathbf{t}$ と疲れ強さとの関係を示して いる．図中の破線は銅を被覆しない軟鋼のみの試験片に よる值である，図によれば銅層が薄くなるにしたがって
疲れ強さは一様に増加しており, $\mathrm{t}=1.5 \mathrm{~mm}$ の場合を除 いて軟鋼だりの場合よりも疲れ強さは高い。また $\mathrm{t}=0$, すなわち軟鋼表面に達する切欠をつけた場合であっても 軟鋼だけの平滑材の值よりもむしろ高くなっている.

しかし平滑な軟鋼一銅材の場台は Fig. 2 のように， 軟鋼だけの場合よりあ逆に低くなっている。

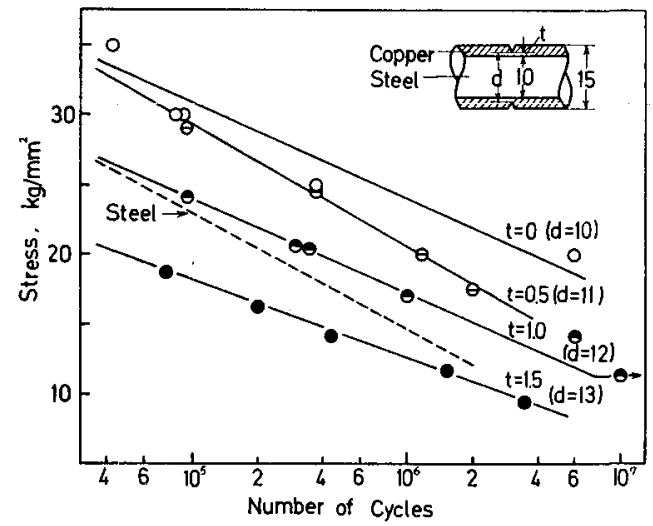

Fig. 1 Fatigue strength of steel-copper composites, notched specimens

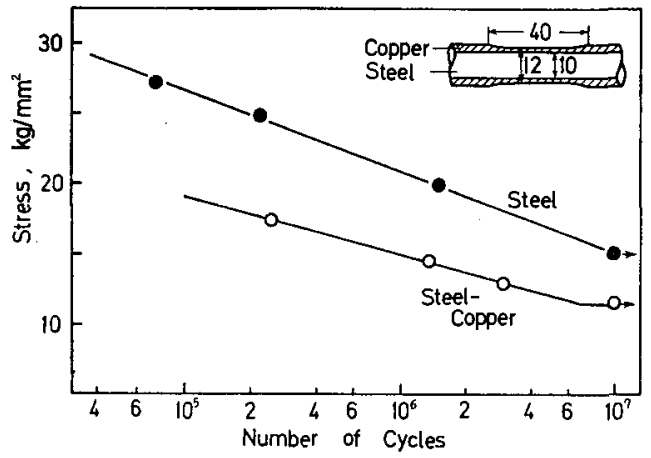

Fig. 2 Fatigue strength of steel-copper composites unnotched specimens 


\section{（19）溶接継手の疲れ強さにおよぼす溶融垔鉊メッキの効果について}

\section{1. 緒 带}

著者の一人は，さきに，軟錐溶㑕部に種々の金属メッ キおよび合成樹脂その他の被㠅をし，その疲れ品さにお よぼす影響を調べ，軟鋁突合せ溶接継手の溶融亚鉛メッ キが特に疲れ強さの局上に効果があるととを報告しだ. 㶱報でほさらにCのような浴融兆鉛メッキによる波れ強 さの改暜の效果が，(1) 切欠感受性の大きい高張力鎆

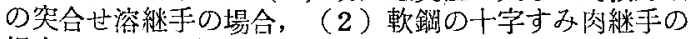
場合および (3) ビード面の比較的滑らかなサブマージ 溶接法による軟鍼突合せ継手の埸合にも期待できる加い なかについて実験を行なった結蝀について報告する。

\section{2. 実験方法およひ結果}

母材の機械的性質を Table 1 亿示す。

板厚 $13 \mathrm{~mm}$ の $80 \mathrm{~kg} / \mathrm{mm}^{2}$ はらびに $60 \mathrm{~kg} / \mathrm{mm}^{2}$ 高 張力銅および板厚 $12 \mathrm{~mm} の \mathrm{SM} 41$ 軟叙を I 型に突合 せて，それぞれ $\mathrm{CO}_{2}-\mathrm{O}_{2}$ アーク溶接法および潜弧溶接法 により両側加ら自動 1 パス溶接を行ない，前記の報告々 同㥞の疲労試験片を採取した。また板厚 $12 \mathrm{~mm}$ のSM 41 軟鋼材を $\mathrm{CO}_{2}-\mathrm{O}_{2}$ アーク溶接法さ 4 ケ所を自動 1 パス溶 接を行ない,完全溶込みの十字すみ肉継手を作り，Fig. 1

$\begin{array}{lllll}\text { 名占屋大学工学部 } & \text { 益 } & \text { 本 } & \text { 功 } \\ \text { 同 大学院 } & \text { 岩 } \text { 田 光 正 }\end{array}$

に示す披労陚験片を採取した。

溶融画敛メッキほ $470^{\circ} \mathrm{C}$ の坐鉛溶融浴に70秒浸漬し， 約 $40^{\circ} \mathrm{C}$ の水浴中に投入して给却吉る。な招, 試片の表 面を炭酸カルシウムの粉末で覆い，乙れとまったく同一 の処理を行い，垔鉛メッキ層の形成を阻止した疲労試験 片により，亚鉛メッキの際の熱処理の効果をも調べた。

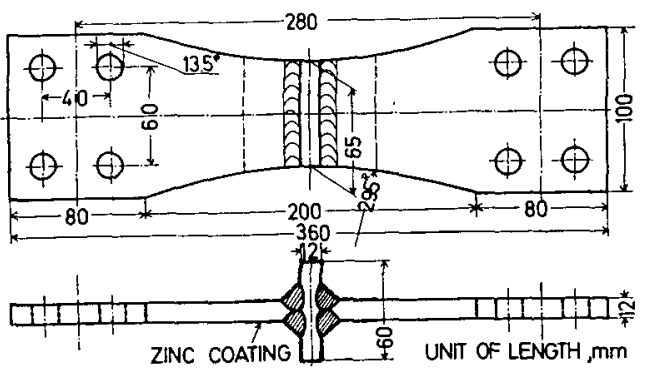

Fig. 1 Fatigue test specimen of fillet welded joint

Table 1 Mechanical properties of base metals

\begin{tabular}{c|c|c|c|c|c}
\hline Base metal & $\begin{array}{c}\text { Ultimate } \\
\text { tensile } \\
\text { strength } \\
\mathrm{kg} / \mathrm{mm}^{2}\end{array}$ & $\begin{array}{c}\text { Yield } \\
\text { strength } \\
\mathrm{kg} / \mathrm{mm}^{2}\end{array}$ & $\begin{array}{c}\text { Elongation } \\
\text { Reduction } \\
\text { area, }\end{array}$ & $\%$ & Use \\
\hline $\begin{array}{l}80 \mathrm{~kg} / \mathrm{mm}^{2} \mathrm{high} \\
\text { tension steel } \\
60 \mathrm{~kg} / \mathrm{mm}^{2} \mathrm{high} \\
\text { tension steel } \\
\text { SM 41 mild steel }\end{array}$ & 87 & 79 & 25 & 67 & Butt welded \\
\hline
\end{tabular}

Table 2 Effect of galvanizing on fatigue strength of various welded joint

\begin{tabular}{|c|c|c|c|c|c|c|}
\hline \multirow{2}{*}{$\begin{array}{l}\text { Welding } \\
\text { process }\end{array}$} & \multirow{2}{*}{$\begin{array}{l}\text { Base } \\
\text { metal }\end{array}$} & \multirow[b]{2}{*}{ Joint } & \multirow[b]{2}{*}{ Treatment } & \multicolumn{2}{|c|}{ Fatigue strength } & \multirow{2}{*}{$\begin{array}{l}\text { Ratio of } \\
\text { increse in } \\
\text { fatiegue } \\
\text { strength to } \\
\text { that of joint } \\
\text { as weld, } \\
\%\end{array}$} \\
\hline & & & & $\begin{array}{c}\text { Number } \\
\text { of } \\
\text { cycle }\end{array}$ & $\begin{array}{l}\text { Stress } \\
\mathrm{kg} / \mathrm{mm} \mathrm{m}\end{array}$ & \\
\hline $\mathrm{CO}_{2}-\mathrm{O}_{2}$ & $\begin{array}{c}80 \mathrm{~kg} / \mathrm{mm}^{2} \\
\text { high } \\
\text { tension } \\
\text { steel }\end{array}$ & $\begin{array}{c}\text { Butt } \\
\text { welded } \\
\text { joint }\end{array}$ & $\begin{array}{c}\text { AW } \\
\text { G } \\
\text { HI }\end{array}$ & $1.5 \times 10^{5}$ & $\begin{array}{l}21.8 \\
28.8 \\
26.4\end{array}$ & $\begin{array}{l}- \\
+32 \\
+21\end{array}$ \\
\hline $\begin{array}{c}\mathrm{CO}_{2}-\mathrm{O}_{2} \\
\operatorname{arc}\end{array}$ & $\begin{array}{c}60 \mathrm{~kg} / \mathrm{mm}^{2} \\
\text { high } \\
\text { tension } \\
\text { steel }\end{array}$ & $\begin{array}{c}\text { Butt } \\
\text { welded } \\
\text { joint }\end{array}$ & $\begin{array}{c}\text { AW } \\
\text { G } \\
\text { H }\end{array}$ & $4 \times 10^{5}$ & $\begin{array}{l}22.0 \\
30.3 \\
28.4\end{array}$ & $\begin{array}{l}- \\
+38 \\
+29\end{array}$ \\
\hline $\begin{array}{c}\mathrm{CO}_{2}-\mathrm{O}_{2} \\
\operatorname{arc} .\end{array}$ & $\begin{array}{c}\text { SM } 41 \\
\text { mild eteel }\end{array}$ & $\begin{array}{c}\text { Fillet } \\
\text { weided } \\
\text { joint }\end{array}$ & $\begin{array}{c}A W \\
\text { G }\end{array}$ & $4 \times 10^{5}$ & $\begin{array}{l}22.7 \\
24.1\end{array}$ & $\begin{array}{l}- \\
+6\end{array}$ \\
\hline $\begin{array}{c}\text { Submerged } \\
\text { arc }\end{array}$ & $\begin{array}{c}\text { SM } 41 \\
\text { mild steel }\end{array}$ & $\begin{array}{c}\text { Butt } \\
\text { welded } \\
\text { joint }\end{array}$ & $\begin{array}{c}A W \\
\text { G }\end{array}$ & $3 \times 10^{5}$ & $\begin{array}{l}21.8 \\
25.1\end{array}$ & $\begin{array}{l}- \\
+17\end{array}$ \\
\hline
\end{tabular}

* AW : as weld

$\mathrm{G}$ : galvanzing at $470^{\circ} \mathrm{C}$, during $70 \mathrm{sec}$ and then water cooling

$\mathrm{H}$; heating in zinc bath at $470^{\circ} \mathrm{C}$, during $70 \mathrm{sec}$ and then water cooling, without zinc layer

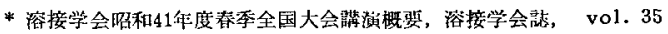

(1966) No. 2, p 156
疲労陚験にほシェン

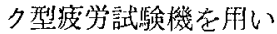

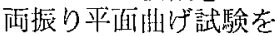
行なった。

拝験結果を総括して Table 2 亿示す. 同表 によれば，高張力堸突 合せ溶接継手の堭合で も溶融亚鉛メッキによ る疲れ触さの增扣加諗 められるが，熱処理の 子に上っても疲倠さ ほかなり增加してい る。また軟鐥十字すみ 肉溶接継于の疲れ強さ 䚾，溶融两鉛メッキに よって同様に增大して いるが，哭合せ継可の 壊合のような著しい效 果ほ示さないようであ 万。

また，潜弧溶按法に

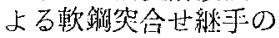
場合屯，溶融亚鉛メッ キによる疲れ蛍さの问 上が明らかに認められ ている. 


\title{
(20) $60 \mathrm{~kg} / \mathrm{mm}^{2}$ 級高張力鋼突合せ溶接継手の疲労特性について
}

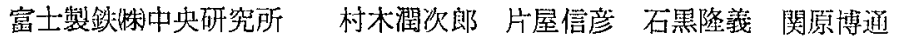

$60 \mathrm{~kg} / \mathrm{mm}^{2}$ 紙高張力鋼突合せ溶接継手の疲労特性に つい高張力鋼溶接継手の㾉労強度の低下が問題しなり 種々の因子について研究されている，手溶接突合継手に ついて見ると溶接金属が健全で溶接法が正しければ，熱 影響部の材質変化，余盛形状，表面黒皮に関係するもの 牫留㐫力によるものなよ゙の原因が考えられている。てれ らのうち著者らは，同一 $60 \mathrm{~kg} / \mathrm{mm}$ 級高張力鐥の熱影響 部材質変化による疲労に対する効果について熱サイクル 再現試験片により検討し, 平滑および切火疲労強度が母 材より低下しないことを確めだ，また余盛帅状の効果 については, R.P. Newman T.R. Gurney ${ }^{2 〉}$ および山口゙” らは Fig. 1 に示すごとく，余盛の高さおよび余盛上表 面とのなす角 $(\theta)$ と疲労強度の関係救めている。しか し，こ扎らついて，この $\theta$ みみでなく，余盛亡板の接 する部分の半径 $(\rho)$ が余盛の形状係数を論ずる上:重 要であると考えられるので, Table 1 のような $60 \mathrm{~kg} /$ $\mathrm{mm}^{2}$ 級高張力銷について类際のビードを盛った継手お

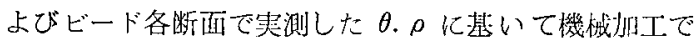
余盛形状を作ったすのにより $150 \mathrm{t} / 100 \mathrm{t}$ ローゼン型疲 学試験機で瘦学試験を行ない，黒皮および研磨母材上比

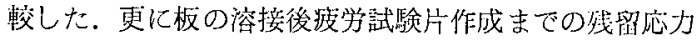
の変化を抵抗線歪㖕により調らべた。結果はFig.2 に示 すごとく溶接のま〉の材料では溶接棒の種類によりค日 の变化は少く，渡篎限度は余り差はなかった。㭙間色度 の上ではイルミナイト柔棒が補修ビードを感ったものが 若干高い値を走した。
研磨母材上黒皮母材との比括よび研磨母材之余盛形状 譏械仕上によるすの上の比加ら黒皮材の乫合せ溶接継手 の疲労限度を推定した值と実测値との間に若干差が見ら れる.これは残留応力の测定值がかなり高い值を示すこ とより残留応力の効果ではないかと考えられる.

\section{参考文献}

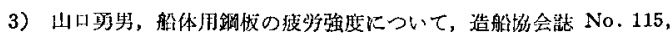
p. $901 / 101$

2) R.P. Newman, T.R. Gurney: Fatigue test of plain plate specimens and Transverse butt welds in mild Steel Brit. Weld. J. Vol. 6, No. 12 p. $569 / 594$

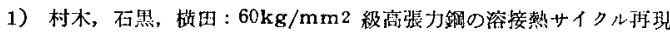
部の渡学特性について，渗接学全誌 Vol. 32 No. 9 p. 122

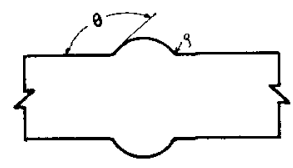

Fig. 1 Shape of weld reinforcement

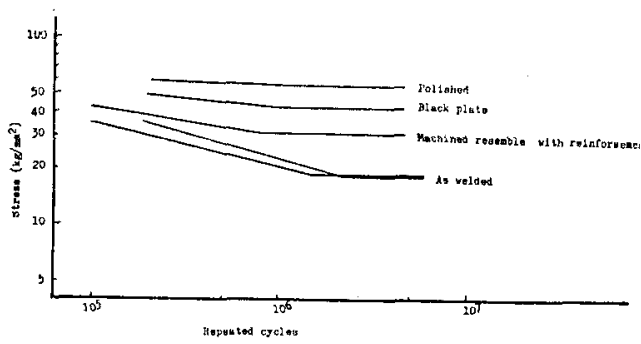

Fig. 2 Fatigue test results of HT-60 steel

Table 1 Chemical composition and mechanical properties of H.T.-60

\begin{tabular}{|c|c|c|c|c|c|c|c|c|}
\hline \multicolumn{6}{|c|}{ Chemical composition (\%) } & \multicolumn{3}{|c|}{ Mechanical properties } \\
\hline $\mathrm{c}$ & $\mathrm{Si}$ & $\mathbf{M n}$ & $P$ & $\mathrm{~s}$ & $\mathrm{v}$ & $\begin{array}{c}\text { Y.S. } \\
\mathrm{kg} / \mathrm{mm}^{2}\end{array}$ & $\begin{array}{c}\text { T.S. } \\
\mathrm{kg} / \mathrm{mm}^{2}\end{array}$ & $\begin{array}{c}\text { El. } \\
\%\end{array}$ \\
\hline 0.15 & 0.26 & 1.27 & 0.012 & 0.013 & 0.016 & & & \\
\hline
\end{tabular}




\title{
（21）薄鋼板のスポット溶接継手の疲れ強さ（第2報）
}

\author{
金属材料技術研劣所 \\ 上田輝之 \\ 東急車耐製造俶横堀章一笼川武雄河高秀年
}

\section{1. 緒 言}

前報に扔いて鉄道車耐の鍶体製作に用いられているス テンレス鋼板（SUS）上炭素鋼板（SPC）の 2 鋼種 3 組 合せの継手の疲れ強さについて報告したが，本報ではス ポット溶接継手の継手設計上㿞要な一因子であるピッチ

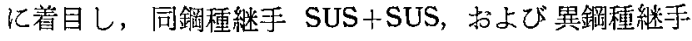
SUS+SPC の症れ強さにおよぼすピッチの影響につい て検討した結果を報告する。

\section{2、実験方法およひ結果}

試験材はステンレス鎝板（AISI-301, 板厚 $1.5 \mathrm{~mm}$ ) と 冷延炭素鎴板（板厚 $1.6 \mathrm{~mm}$ ) を使用した。供試材の化 学成分および機械的性兵を Table 1 亿示す。試験片は 第 1 報で述べた溶接条件（静的引張強さが最高になる条 件）で溶接した。 ピッチは 8,10,13,20,30,40,45,60 mm の8 種類とした。試験片の形状寸法は Fig.2 亿示す.疲 れ試験は片振引張荷重で行ない，それとともに静的引張 試験も行ないピッチの変化による継手の静的強度の変化 も検討した，静的引張試験の結果(SUS+SUS)を Fig. 1 に示す. Fig. 1 に示すように，ピッチ $10 \mathrm{~mm}$ 前後まで はピッチの減少（打点数の增加）とともに静的㧧度（公 称迈力）は指数函数的に增加するが，ピッ千がそれ以上 小さくなると腾的踽度は一定值に近づき，增加しない。

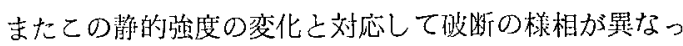

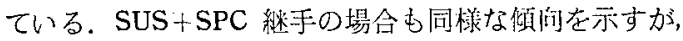
刘応する破断の㥞相は異なる。

Fig. 2 はUS+SUS 継決の披扎試験結果であり，波

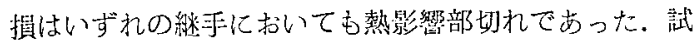
験結果を 1 点当りの峦さに换算して比較すると，ピッチ の差異による隐度の変化が認められ（傾问としては静的

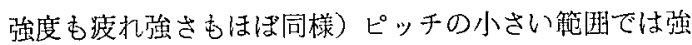
度は低く，ピッチの增加とともに强度は増大し，あるピ ッチ以上になると強度は一定值に近づく傾局が認められ た.この静的強度之疲れ強さの比を示したのが Fig. 3 である.SUS+SPC 継手では，この比はピッチの変化 にかっわりなくほぼ一定の傾向を示すが，SUS+SUS継 手では時間強度の上りかたによってピッチの影響が異る 傾问を走した。

1点当りの出度に認められた差を検討するためナゲッ 卜端の応力を抵抗線歪ゲージを用いて測毞し，ピッチの
差異によるナゲット端の応力集中の変化を求めた. また この結果加ら疲独さに対するピッチの影響について若 干考察した。

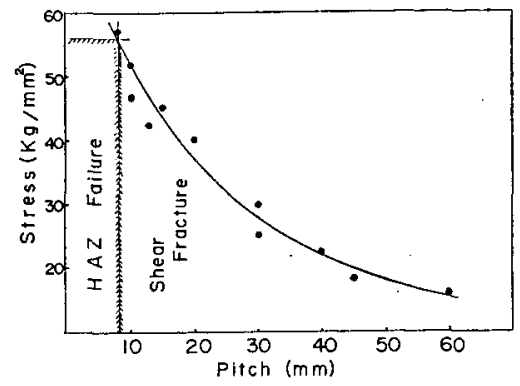

Fig. 1 Static strength for spot welded joint of stainless steel sheets

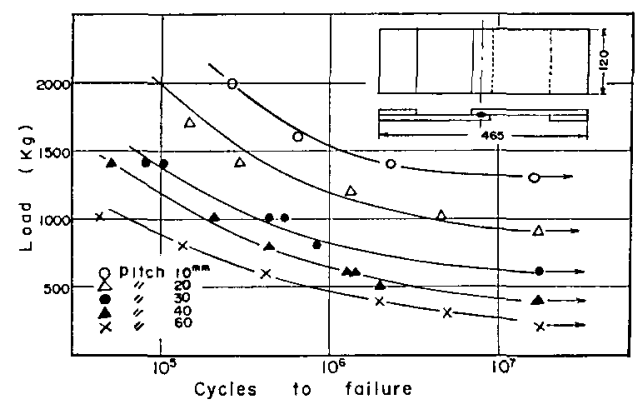

Fig. 2 Fatigue strength for spot welded joint of stainless steel sheets

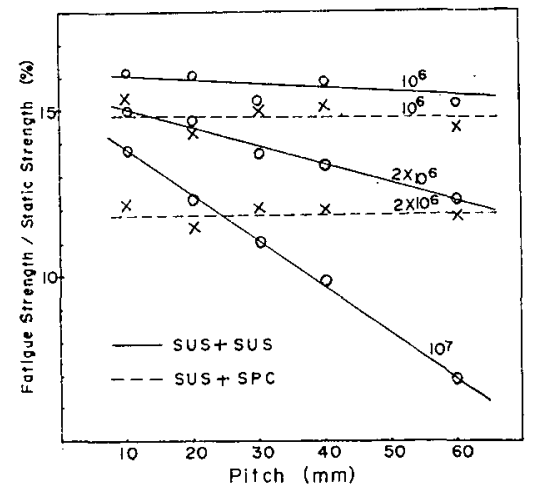

Fig. 3 Ratio of fatigue strength to static strength of spot welded joints

Table 1 Chemical composition and mechanical Properties of base metal

\begin{tabular}{c|c|c|c|c|c|c|c|c}
\hline Test material & $\mathrm{C}$ & $\mathrm{Si}$ & $\mathrm{Mn}$ & $\mathrm{Cr}$ & $\mathrm{Ni}$ & $\mathrm{T} . \mathrm{S}(\mathrm{kg} / \mathrm{mm} 2)$ & $\mathrm{Y.P}(\mathrm{kg} / \mathrm{mm} 2)$ & $\mathrm{El} \mathrm{( \% )}$ \\
\hline SUS & 0.10 & 0.70 & 1.16 & 17.71 & 6.78 & 75.0 & 36.0 & 35.0 \\
S PC & 0.07 & $\mathrm{Tr}$ & 0.29 & - & - & 31.0 & - & 49.0 \\
\hline
\end{tabular}




\section{（22）原子炉用 HT 70 鋼大型溶接継手のクリープラプチヤに 関する研究（第4報）}

一设断梯相に刘する検討——

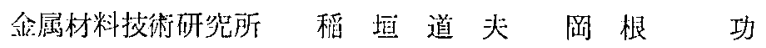

緒言；前報までに，原子为任力容器用として試作さ れた板厚 $30 \mathrm{~mm}$ の70キ口級 $\mathrm{Mn}-\mathrm{Cr}-\mathrm{Mo}$ 系調質型高張 力䤱溶接継手のクリープラプチヤ試験を大型および小型

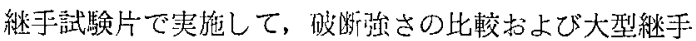
試験片の破䉼機棒の倹討を行なっだ)2 . 本報は主として 大型継手試験片々小型継手試験片の破断状態の相違につ いての検討およびクリープ破断状態からみた溶接施工法 の検討結果について報告する.

内容； 大型継手試験片は溶接継手形状をそのまま有 しているのに対して，小型継手試験片は継手部中心附近 より採取している．本供試鐦の板厚は $30 \mathrm{~mm}$ で，その 溶接は当然多層盛で行なわれる，このため，両試験片の 継手部の性質は当然異なっていると考えられる。こ机が 破断状態の相違汇関係しているように思われる，大型継 手試験片の破断については，前報で報告したように破断 はボンドに沿った母材㠇影響部粗䊉域で生じている。 ま たクリープ破断紗さを高温引張試験に㧍ける破断まで の吸収エネルギーの大小で比較し得ることを明らかにし $た^{22}$. しかし，小型継手試験片の破断個所は母忉熱影響 部微粒域であり，しかも多重溶接熱サイクルを受けて母 材熱影響部は繰这し㴈なまされている関係上，上記の破 断機構は適用できない，本報では小型継手試験片の熱影 響部の各位置の組織を小型丸棒試験片に再現して，乙れ で $450^{\circ} \mathrm{C}$ 、に求ける引張破断までの吸収エネルギーを求

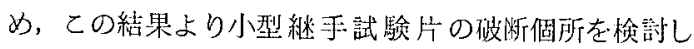
た。この結果上前報の結果とを比較して大型掞よび小型 継手試験片の破断状態の相蓳を解明した。 Table 1 は小

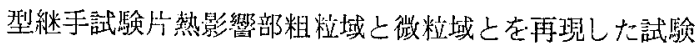
片の $450^{\circ} \mathrm{C}$ 上常温におりる引張試㸛絬果である。この 結果より旪断までの吸収エネルギーを求めると, 粗粒城
: 微粒域 $=1: 0.92\left(450^{\circ} \mathrm{C}\right)$ で微粒城の力が小さい。 れより本試験の温度䈥团 $\left(400 \sim 500^{\circ} \mathrm{C}\right)$ においての小型 継手試験片のクリープ睃断個所は大型継手試験片の場合 と異なり母材熱影響部微䊉域であることが推察できる.

大型継手試験片のクリープ吸断形状は本筷験では Fig. 1 亿示すような 2 種類に分類できる。 この形状を種々検 討した結果, 最終溶接層の施工に際しては, 止端部のボ ンドと母材板面との触をできうる限り大きく，すなわ ち，浅い溶込みになるような溶接条件を選尘するこ上は 破断強さを向上させるためには望ましいととが判明し た。

\section{参，考 文 献}

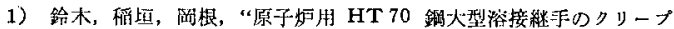

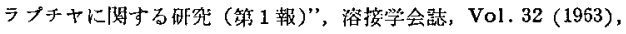
No. 9, p. 805 811

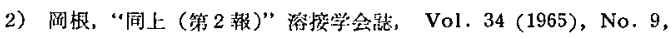
p. $903 \sim 910$

Table 1 Results of tensile test for the specimens submitted to repeated thermal cycle

\begin{tabular}{c|c|c|c}
\hline Grain zize & $\begin{array}{c}\text { Test temp. } \\
\left({ }^{\circ} \mathrm{C}\right)\end{array}$ & $\begin{array}{c}\text { Strength } \\
\left(\mathrm{kg} / \mathrm{mm}^{2}\right)\end{array}$ & $\begin{array}{c}\text { Elongation } \\
(\mathrm{GL}=30 \mathrm{~mm}) \\
(\%)\end{array}$ \\
\hline \multirow{2}{*}{ Coarse } & 25 & 106 & 10.4 \\
& 450 & 85.7 & 12.8 \\
\hline \multirow{2}{*}{ Fine } & 25 & 101 & 11.2 \\
& 450 & 84.6 & 12.0 \\
\hline
\end{tabular}

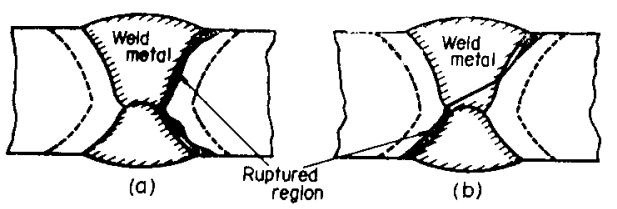

Fig. 1 Creep rupture configuration of large welded specimens 
（23）高温高圧用 $3 \% \mathbf{C r}-1 \% \mathbf{M o}$ 鋼の高温特性と溶接継手について

\section{日本製鋼侏室蘭宮野樺太男進藤弓弦松田明}

\section{1.まえがき}

最近，石油精製工業の急速な発展上と屯にをれに使用

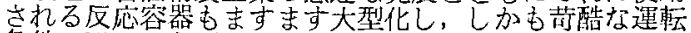
条件に测える必要加ある。例えば Hydrocracking processにおける反応容器で㳘温強度および耐水菜性より Cr-Mo 鈯が使用される，操業温度扎よび死力の関係加 ら ASTM-A $387 \mathrm{Gr} . \mathrm{E}(3 \% \mathrm{Cr}-1 \% \mathrm{Mo})$ 鎹まで使用さ

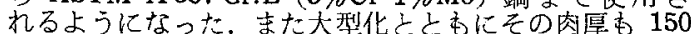
$\mathrm{mm}$ 越えるような場合多多いししたがっててのような 極厚の $3 \% \mathrm{Cr}-1 \% \mathrm{Mo}$ 鋼の溶接継手部の性能は最す重要 な問題である。

本報告は極厚の反応容器を対象として，3\% Cr-1\% Mo

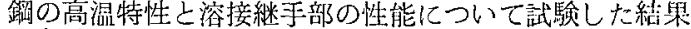
である。

\section{2. 試験方法および試験結果}

使用目材の化学成分を Table 1 亿示学. Fig. 1 は目 牨の常温ならびに高温におりる引張試験絬果である。 Fig. 1 から明らかなごとく $468^{\circ} \mathrm{C}$ を境にして高温治度 が念激に低下する。こ扎は本銅材は $470^{\circ} \mathrm{C}$ 前後加らク

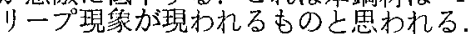

使用溶接材料は心線加合金元素の添加されるA型上 被蕧剂ま大はフラックスから添加されるB型の 2 種類の ものを手動および自動溶接について選定した。予熱およ び層間温度はすべて $250^{\circ} \mathrm{C}$ とした。それぞれの溶着鈿

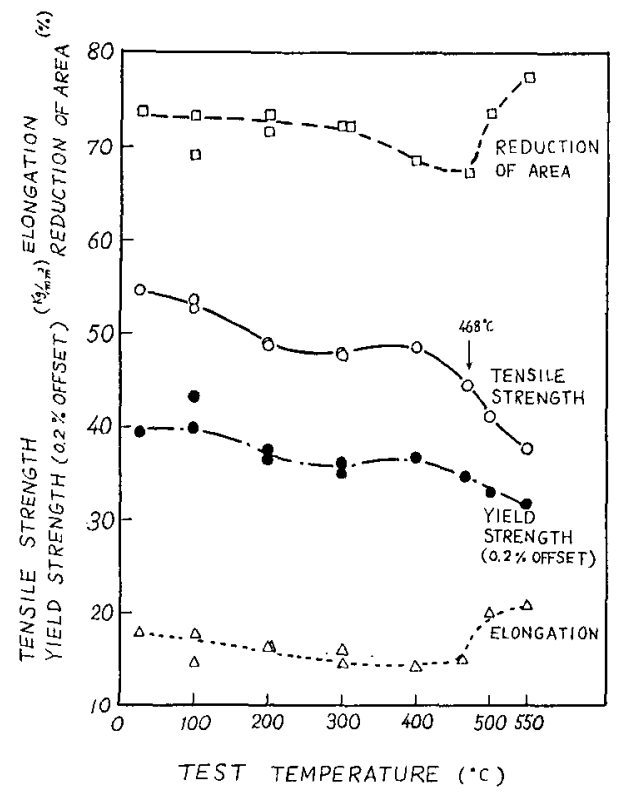

Fig. 1 Mechanical properties of base metal
の化学成分を Table 1 亿示す.

Fig. 2 は Table 1 k示した溶着鎐を $690^{\circ} \mathrm{C}, 720^{\circ} \mathrm{C}$, $740^{\circ} \mathrm{C}$ で焼鈍し，常温および $468^{\circ} \mathrm{C}$ で问层試験をした ときの引張婱さ SR と温度の関係である。

これらの結果から明らかなごとく手溶接の場合，合金 元素の添扣法依異なっていて車全溶者金属の化学成分は 母材相当であり成分上問題はないが，自動溶接ではフラ ックスから合金元素を添加したものは Cr, Mo 量が多 w.

全溶着金属の引涱特性は $\mathrm{SR}$ 温度 $690^{\circ} \mathrm{C} \sim 740^{\circ} \mathrm{C}$ の 間では高温度はど強度がほぼ直線的に低下し,手敌溶接， 自動溶接しも心線加合金元素を添加したものの力が留

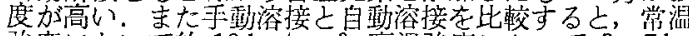

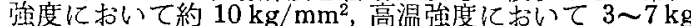
$/ \mathrm{mm}^{2}$ 手動溶接の方が高い.さらに Fig. 1 の母材の引 㖘強さ之比較守る上, 手䡃溶接の場会, 目材上り屯相当 㔖度が高い。この倾同は常温の方が多い。自動溶接では

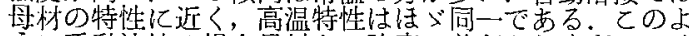
5に手勤溶接の場合母材との強度の差がありすぎるため 継手では多少問題がある亡思われる。

さらに極厚釗に多層溶接した場合の継手部の特杵や辰 時間加熱による溶接部の脆化についても策験した。

以上の試験結果より $3 \% \mathrm{Cr}-1 \% \mathrm{Mo}$ 鈮の溶接部 0 外能 はいずれの場合も，ほぼ完全なものが得られた。

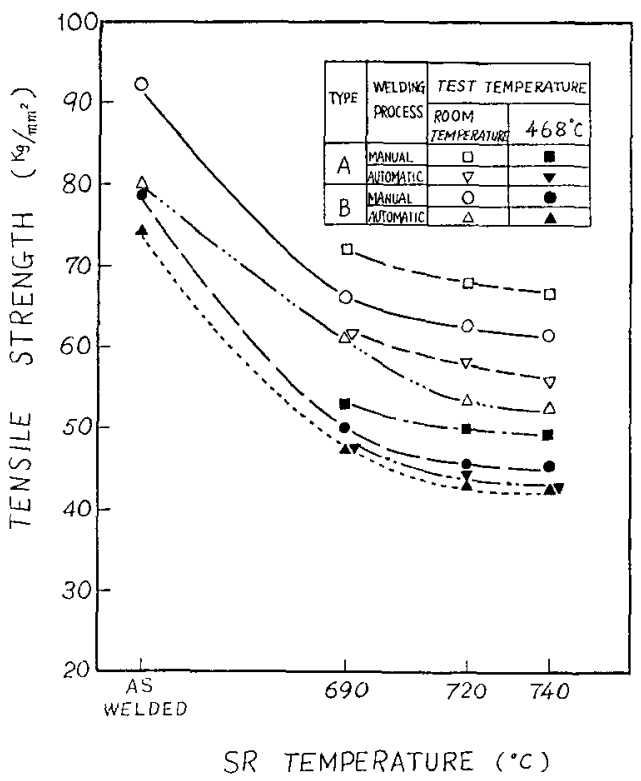

Fig. 2 Relation between SR temperature and tensile strength of deposited metal

Table 1 Chemical composition of base metal and deposited metals

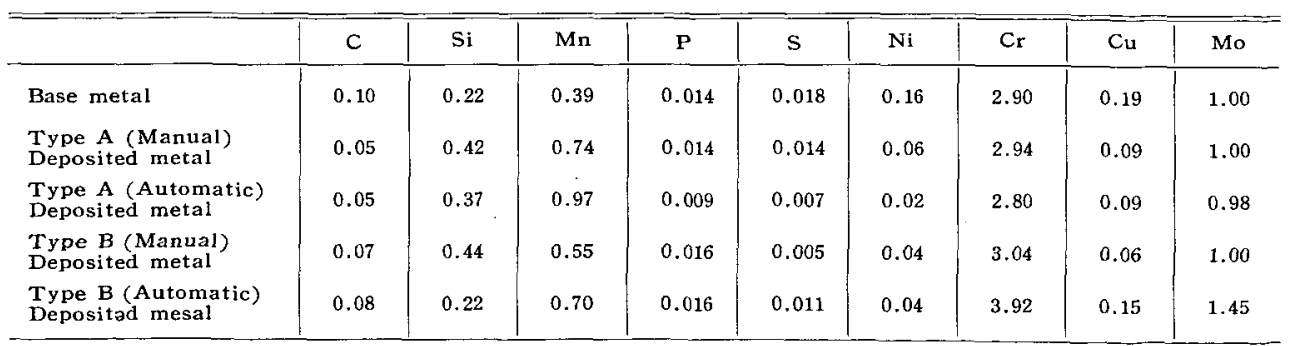




\section{（24）数種の鋼材の高速回転衝撃試験}

東北大学 小林卓 郎 平間一臣

VEB Materialprüfung（Leipzig）製回枟衝整試験機 を用いて，低温用鋼，高㖘力鋼，欶鋼など各種鋼の衝揧 妯げ破壇試験を行なった。この試験機は $5 \sim 50 \mathrm{~m} / \mathrm{sec}$ 間 の任意一定の速度で曲げあるいは引張試験を行ない，試 験中の荷重変形図を写萁記録できるむのである。

使用した鋼材は，低温用鋼 3 種（LTC-410QT, LTC$\mathrm{AlK}, 2.5 \mathrm{Ni}$ ), 高張力銅 3 種 (HITEN 70, SM $60 \mathrm{~A}, \mathrm{SM}$

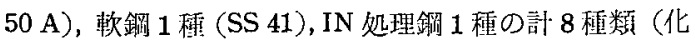

SS-41

Impact Velocity $40 \mathrm{~m} / \mathrm{s}$
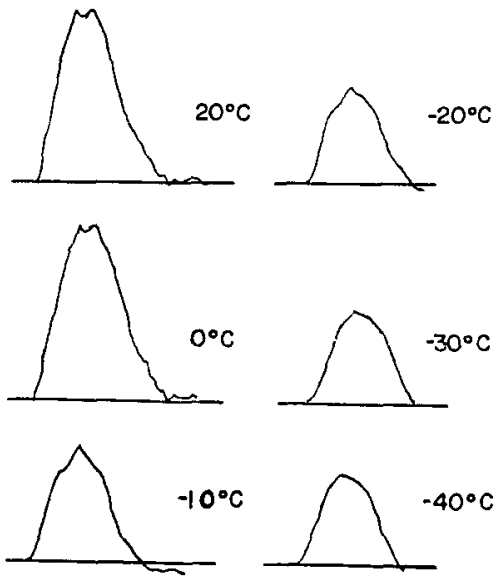

Fig. 1

SS - 4

Impact Velocity $20 \mathrm{~m} / \mathrm{s}$
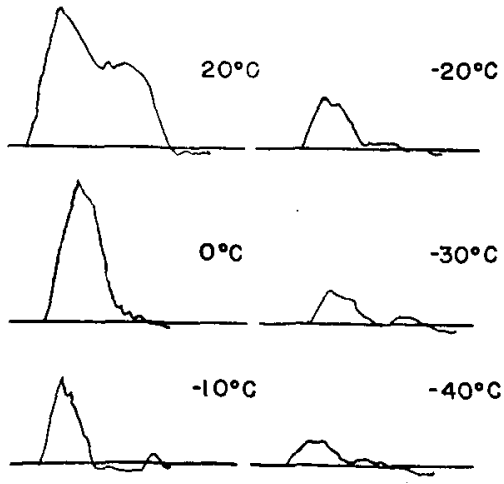

Fig. 2

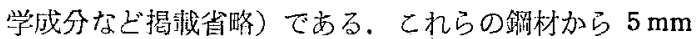

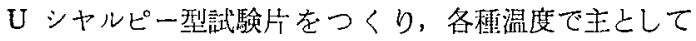
$40 \mathrm{~m} / \mathrm{sec}$ で，一部については $20 \mathrm{~m} / \mathrm{sec}$ および $6 \mathrm{~m} / \mathrm{sec}$ の逶度で㫐試験した．SS 41 についての Load-Deflection Diagram Fig. 1,2,3 飞示す。横軸は Deflection, 緹 軸は Load を示している。本試験機によると， Energy， Deflection, Max. Load の各々について暧移状海が明に 認められることがわかるであろう。ただ，試験温度が比 較的高いかかるいは变形速度が小さい場合の場合 (Fig. 2 て $20^{\circ} \mathrm{C}$ の場合, Fig. 3 て $-10^{\circ} \mathrm{C}$ 以上の試験温度 の均合）の Load-Deflection Diagram で Max. Load 以 後にあらわれるジグザグ腺の解釉は現在のところ明確 だね.

試缽温度が脆性遷移温度以上の場合には，Max. Load は変形速度の增大および温度降下とともに大きくなる。 $40 \mathrm{~m} / \mathrm{sec} の$ 埸合の $\mathrm{Max}$. Load-Testing Temperature の関係を Fig. 4 に示す。.

\section{SS-41}

Impact Velocity $6 \mathrm{~m} / \mathrm{s}$
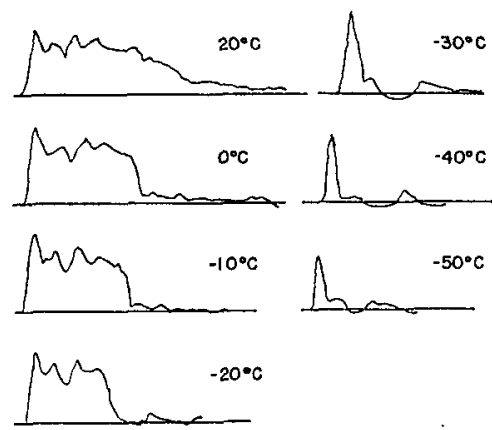

Fig. 3

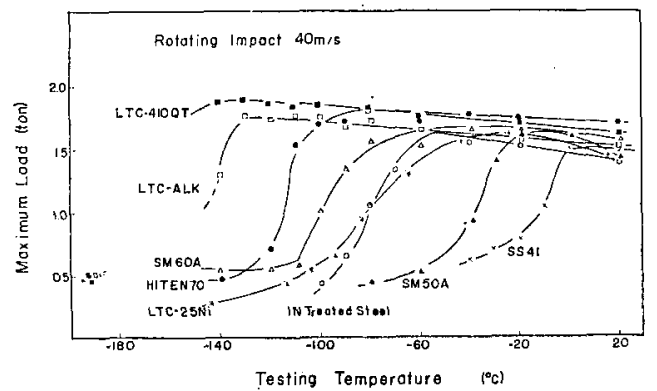

Fig. 4 
（25）厚板13クローム鋼溶接部の低温衝撃值および硬さに

\section{およぼす後熱条件の影響}

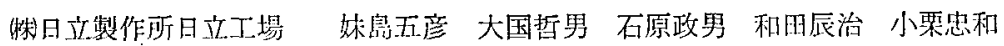

\section{1.緒言}

13クローム堸は焼㞔し脆性を示す性質があるので，特 に厚板材で硬度の高い材料（220〜250 BHN クラス）は

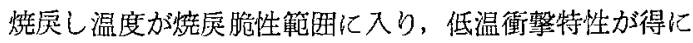
くいので，適量の Ni 量の添加と熱姏理がほよ゙こされて いる.

合せてこの種厚板13クローム鋼板をオーステナイト系

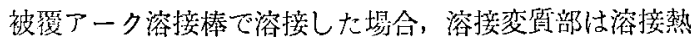
サイクルの影響を受けてさらに衙整值の低下および硬度 の上昇が考えられる.特に大型溶接構造物では浴接後, 応力除去, 軟化㜔鈍を行なう必要があり，烧鈍後の溶接 継手部の低温衝整特性が問題となる。今回の報告ではか かる見地より厚板13クローム鋼溶接部の低温荇撃特性お よび，硬さにおよ括す後熱条件について報告する。

\section{2. 実験方法}

Table 1 亿供試鉬の化学成分扝よび機械的性質，供試 溶按棒の主な仕様を示す。実験は鋼板上に樑さ $15 \mathrm{~mm}$ のV形開先をほり，直流迹極性で予熱 $150^{\circ} \mathrm{C}$ 以，層 間温度 $250^{\circ} \mathrm{C}$ 初焦 $4 \mathrm{~mm}$ 径 $140 \sim 170 \mathrm{~A}, 2$ 層 6 層 $5 \mathrm{~mm}$ 径 $180 \sim 230 \mathrm{~A}$ の溶接条件で溶接を行ない各後熱 炕理它行なったあと，ボンド部 H.A.Z.の $2 \mathrm{~mm} \mathrm{Vノッ}$ チシャルピー值と硬さ測定を行なった。

つぎに $42 \mathrm{~mm}$ 厚板のX型開先溶接継手試験を $625^{\circ} \mathrm{C}$ $3 \mathrm{HR}, \mathrm{F} \cdot \mathrm{C}, 660^{\circ} \mathrm{C}, 3 \mathrm{HR}$. A.C, $700^{\circ} \mathrm{C} 3 \mathrm{HR} \mathrm{AC}$ 処理 した場合の継手性能につき調楂した。

\section{3 、実験結果}

$-10^{\circ} \mathrm{C}$ に方りる衝整值圭 $15 \mathrm{ft}-\mathrm{lb}(2.07 \mathrm{~kg}-\mathrm{m})$ 以 上という基準て考えるとしれを㴼足する後熱条件は No. 1 , No. 2 , No. 5 , No. 6 の 条件である. $600^{\circ} \mathrm{C} の$ 後䓡では H.A.Z. の硬さが低下しないので適当でない.
(No. 1) ボンド部は $660 \sim 700^{\circ} \mathrm{C}$ の焼厣しで比較的良好 な衙撃値を示すが H.A.Z に此較して低く，特に $720^{\circ} \mathrm{C}$ $\times 3 \mathrm{HR}$ の後熱処理では $\mathrm{A}+\mathrm{M}+\mathrm{F}$ 組織が後熱処理によ b $\delta \rightarrow \sigma$ 変態をおこしシグマ脆化する. (No. 4) H.A.Z. は後熱温度が高くなるにつれ烓入れ組織が焼戻されるの で衝撃值は问上する.（No.6, No 7) 溶着金属について は $700^{\circ} \mathrm{C}$ 前後の後熱温度ではシグマ脆化をおしし街整 傎が低下するのでさけなければならない（No. 7)

以上の結果之供試䤾の焼厣温度 $690^{\circ} \mathrm{C}$ を考慮して, 後熱条件ししては $660^{\circ} \mathrm{C} \times 3 \mathrm{HR} \mathrm{A} \mathrm{C}$ 処理が最適と判断 される。この溶接施工条件ですって，フエライト最孛 7.5〜10\%になるような309タイプの溶接棒ですって溶接 した結果は No.6亿示すごとく良好な性能が得ら扎るこ とがわかった。な挔登時には後熱処理による炭化物の 粒界析出，および脱炭痼の生成についても附言する。

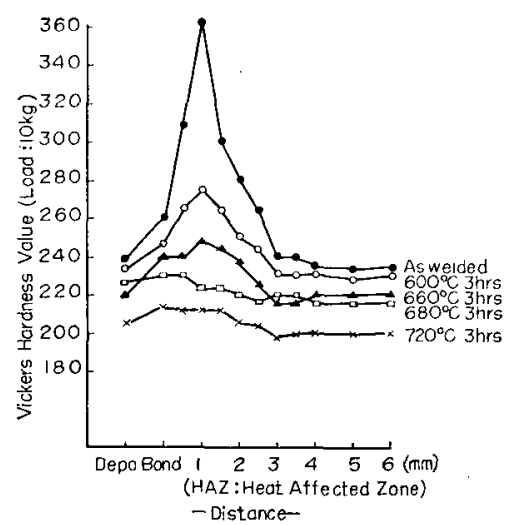

Fig. 1 The affect of post heat temperature on $13 \mathrm{Cr}$ seeel weldments

Table 1 Chemical compositions and mechanical properties of base metals, electrodes and weld metals

\begin{tabular}{|c|c|c|c|c|c|c|c|c|c|c|c|c|c|c|c|}
\hline \multirow{2}{*}{ Materials } & \multicolumn{8}{|c|}{ Chemical cnmpositions (per-cent) } & \multicolumn{6}{|c|}{ Mechanical properties } & \multirow{2}{*}{$\begin{array}{l}\text { Ferrite } \\
\text { value }(\%)\end{array}$} \\
\hline & $\mathrm{C}$ & $\mathrm{Si}$ & $\mathrm{Mn}$ & $\mathbf{P}$ & $\mathbf{s}$ & $\mathrm{Cr}$ & $\mathrm{Ni}$ & Mo & $\mathbf{Y} \mathbf{P}$ & TS & EL & RA & $\mathrm{H}_{\mathrm{V}}$ & Impact value & \\
\hline $\begin{array}{l}\text { *Base metal } \\
\text { SUS-50 HP } \\
\text { (Thick: 42) }\end{array}$ & 0.12 & 0.40 & 0.44 & 0.024 & 0.006 & 13.15 & 0.60 & - & $\left|\begin{array}{c}60.4 \\
\mathrm{~kg} / \\
\mathrm{mm} 2\end{array}\right|$ & $\left|\begin{array}{c}73.8 \\
\mathrm{~kg} / \\
\mathrm{mm}^{2}\end{array}\right|$ & $\begin{array}{c}27.2 \\
\%\end{array}$ & $\begin{array}{l}65 \\
\%\end{array}$ & 241 & $\begin{array}{l}3.4 \mathrm{~kg} \cdot \mathrm{m} / \mathrm{cm}^{2} \\
3.4 \\
2.18 \\
\left(\text { at }-10^{\circ}\right) \\
\end{array}$ & - \\
\hline $\begin{array}{l}\text { Electrodes } \\
309 \text { Mo type } \\
\text { Titania type }\end{array}$ & 0.09 & 0.30 & 1.30 & - & - & 21.32 & 12.13 & 1.90 & - & 58.3 & 39.3 & 53 & - & $\begin{array}{l}10.5 \mathrm{~kg}-\mathrm{m} / \mathrm{cm}^{2} \\
11.39 \\
10.73 \\
10.39 \text { (at RT) }\end{array}$ & $7.5-10$ \\
\hline
\end{tabular}

* Heat treatment on base metals; Quenching $\left(950^{\circ} \mathrm{C} \times 2 \mathrm{hrs} \mathrm{AC}\right)+$ Tempering $\left(690^{\circ} \mathrm{C} \times 3 \mathrm{hrs} \mathrm{AC}\right)$ 


\section{（26）片側切欠付小型引張試験片による破壊発性特性について}

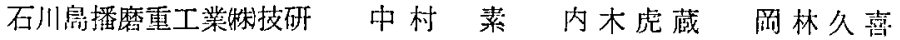

\section{1. 緒 곰}

軟鋼を低応力做壊さすためには，Deep notch test 武 験片のごとく北状を大きくする必琶があるが，溶接熱影 響部の試験, あるいは安価, 便利さの点より試験片は小 型であることが望ましい. 片侧切欠付引張試馱片におい ては曲げモーメントが生じ，全面降伏の傾问が小となる 点に注目して，小型試験片を開発した。またこの試験 を用いて佊烄の発生について周べた。

\section{2. 実験法}

供試材としては Table 1 に示すごとき市販80キロ級

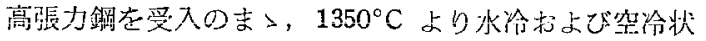
隹下で試験した。

試験片の非状寸法を Fig. 1 亿示す，荷重負荷時の㓶 れの变化は高速撮影かよび電気抵抗法によって測定し

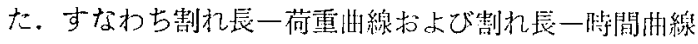
を㧗いた。

\section{3. 結果および検討}

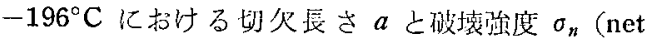

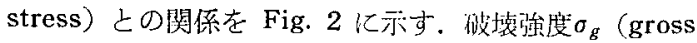
stress) 上の関係は

$$
E G=\sigma^{2}{ }_{g} w f(a / w)
$$

で表わすととができる，Eはヤング來， $G / 2$ は表面暗 性エネルギー， $f(a / w)$ は形状で起まる係数であり Fig. 2 に示す. Fig. 3 に $G$ および $\sigma_{n}, \sigma$ 温度依存性を示 す. $\log G^{-}$温度をとると良い值螕性が得られる。疫学割 れをつけない舅合は佊壊强度は增加する。

破壊の様式としては，完全䏧性佊面の領域では発生と

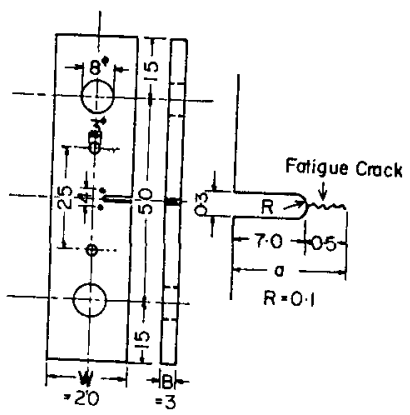

Fig. 1 Test specimen and detail of notch part

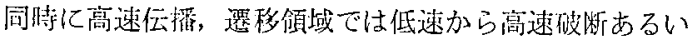
は発生から高速伝播そして停止となった。さらに外力な 加えれば低速から高速となり破炘した．完全延性破壊の 領域では低速から高速破断：連続的に変化した。

以上の割机の速度の点より不安定破壊の条件について 再検討を加えた。な杉本試娩とシャルピ一試験の結果に ついて此較检期した。

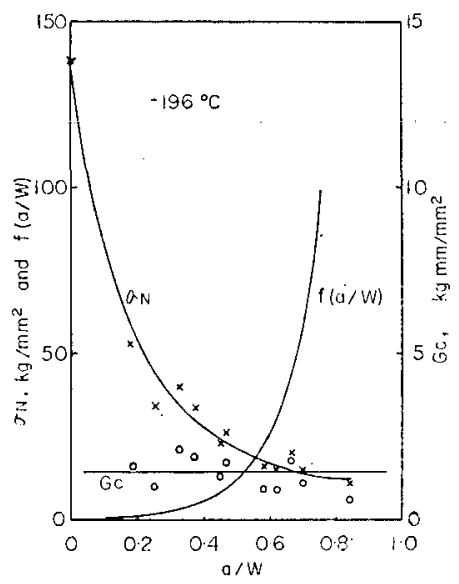

Fig. 2 Relationship between fracture properties and crack length

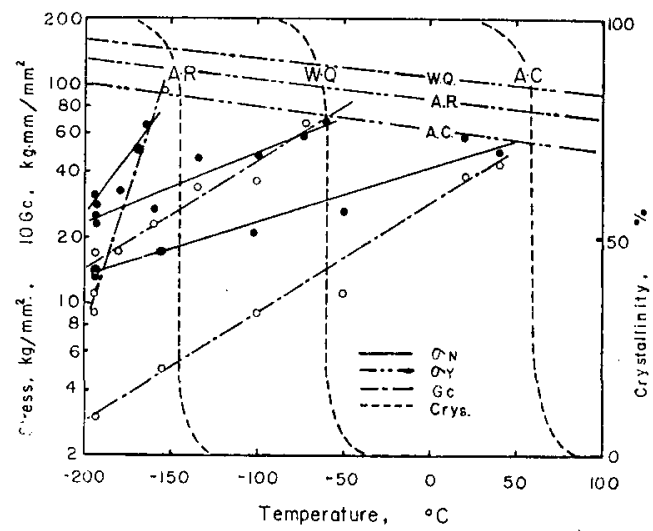

Fig. 3 Relationship between fracture properties and test temperature

Table 1 Chemical composition and mechanical properties of HT 80 plates used

\begin{tabular}{l|c|c|c|c|c|c|c|c|c|c|c|c|c|c|c|c}
\hline \multirow{2}{*}{ Material } & \multicolumn{10}{c|}{ Chemical composition (\%) } & \multicolumn{3}{c}{ Mechanical properties } \\
\cline { 2 - 11 } & $\mathrm{C}$ & $\mathrm{Si}$ & $\mathrm{Mn}$ & $\mathrm{P}$ & $\mathrm{S}$ & $\mathrm{Ni}$ & $\mathrm{Cr}$ & $\mathrm{Mo}$ & $\mathrm{Cu}$ & $\mathrm{V}$ & $\mathrm{B}$ & $\begin{array}{c}\text { Y.S. } \\
(\mathrm{kg} / \mathrm{mm} 2)\end{array}$ & $\begin{array}{c}\mathrm{T} . \mathrm{S} . \\
(\mathrm{kg} / \mathrm{mm} 2)\end{array}$ & $\begin{array}{c}\text { El. } \\
(\%)\end{array}$ \\
\hline HT 80-U & 0.15 & 0.19 & 0.78 & 0.016 & 0.007 & 0.73 & 0.40 & 0.44 & 0.27 & 0.04 & 0.005 & 83.0 & 89.0 & 23 \\
HT 80-Y & 0.17 & 0.18 & 0.89 & 0.010 & 0.008 & 0.007 & 1.10 & 0.45 & 0.29 & 0.006 & $\mathrm{tr}$ & 78.0 & 87.0 & 23 \\
\hline
\end{tabular}




\section{（27）高張力鋼溶接部の切欠強度について}

石川鿼播磨重工業㮫拼 中村 素 内木虎蔵 岡林久喜

\section{1.緒言}

比較的入熱の大きい力法で溶接した高张力鋼の継手部 は低温で低応力破壊を起こすととが認められる。この問 題を明らかにするために溶接部の皮填強度について調心゙ た。

\section{2. 供試材}

各種市贩鎆の内一例として80キ口級高張力鐝を取挙げ ることにする。

\section{3 ，実験内容}

Fig. 1 のごとく，開先に一屇ビードを置き，そこから 片側切火付小型引張試験片を採取した。切火は試験目的 位置に図のごとくいれた。ビードは，下向执よび吉问姿 勢の手溶按によって入熱を 8〜67 K Joule/cm, 甬熱を $40 \sim 150^{\circ} \mathrm{C}$ と変化させて置いたすのである.

降伏強度なよ゙機械的性憵については，疑似溶接熱けイ クルを与えた材料の試験絬果で代用した。
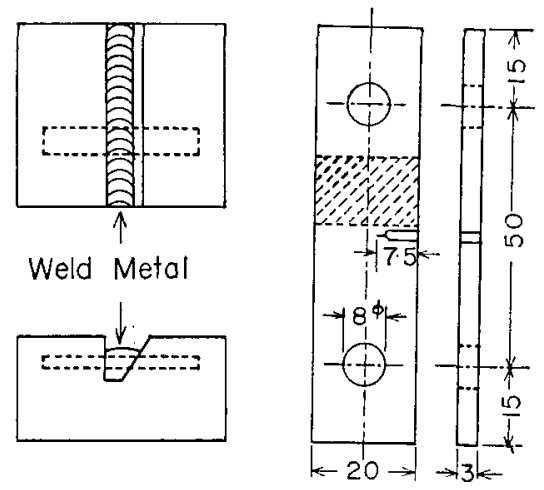

Fig. 1 Test specimen

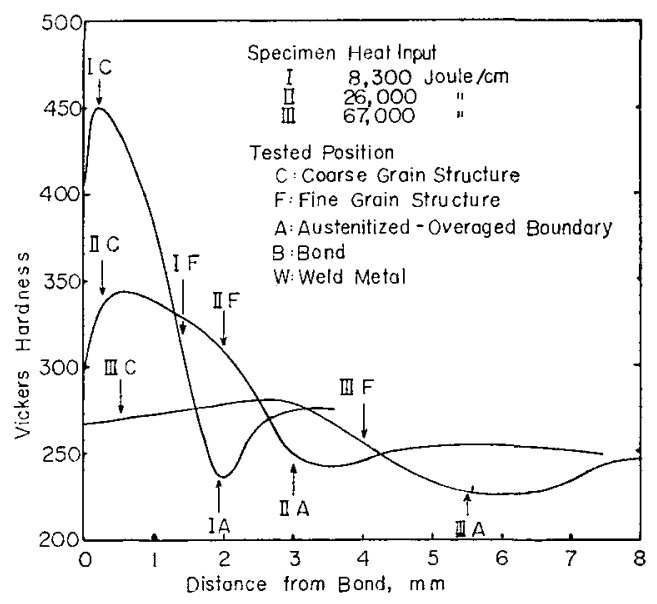

Fig. 2 Heat-affected zone hardness and tested positinn
Fig. 2 に溶接部の硬さと試験位置を示す.すなわち溶 若物, 溶融線上, 硬度の最高部, 細粒部, 軟化部および 曹材原質部について試験した。

Fig. 3 および Fig. 4 亿入熱 $27 \mathrm{~K}$ Joule/cm および $67 \mathrm{~K} \mathrm{Joule} / \mathrm{cm}$ の溶接部の破塄強度 $\sigma_{N}$ (net stress) および表面塑性エネルギー $G / 2$ を示す， $G$ は次の式よ り求めた:

$$
E G=\sigma_{g}^{2} w f(a / w)
$$

$\sigma_{g}$ は Gross stress, $f(a / w)$ は形状による係数である。

これらの結果より明らかなごとく溶接線に極近傍の熱 影響部の少化は大きく，一般に $60 \mathrm{~kg} / \mathrm{mm}^{2}$ 級以上の高 張力鋁においては入熱の增加とと屯に切欠強度は低下す ることが楒められる。この結果は広巾溶接継手試験の結 果と良く刘応している．広门試験および溶接構造物との 関係，応力除去焼鈍の効果についても検討した。

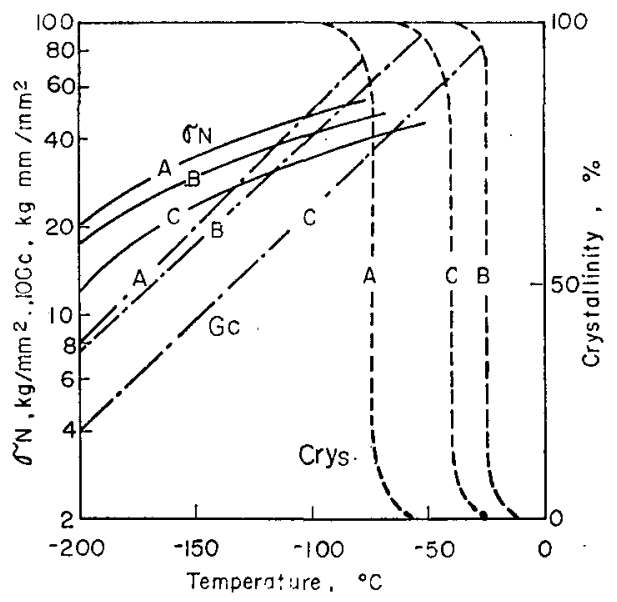

Fig. 3 Relationship between temperature and fracture properties in case of heat in put $27 \mathrm{KJ} / \mathrm{cm}$

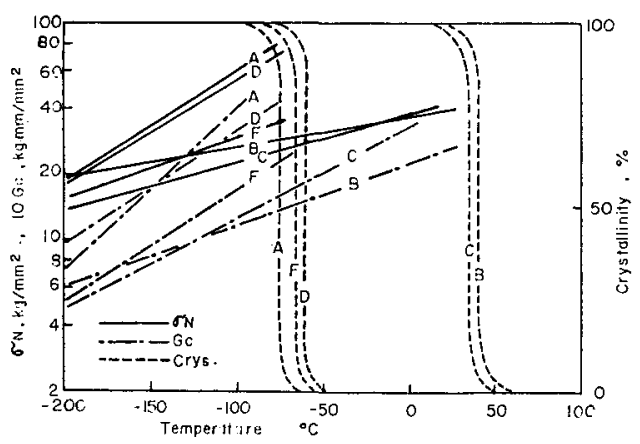

Fig. 4 Relationship between temperature and fracture properties in case of ueat input $67 \mathrm{KJ} / \mathrm{cm}$ 


\section{（28）高張力鋼溶接熱影響部の性質について（第2報）}

（拘束状態下での熱サイクル再現部の切久勒性）

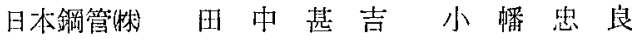

\section{1.緒言}

第 1 報にて，熱サイクルのみによる切欠靱性の变化を 報告したが，実際の溶接部は母材部の荷束を受け熱間に て塑性変形を受ける。この拘束の効果を検討するため, 拘束状態に打りる熱サイクル再現試験を行ない，切欠靶 性におよぼす拘束の影響を調查したのて，その絬果を報 生する。

\section{2、実験方法}

供試鋼材として，SM 50 および泟型型の HT 60，HT 70、HT 80 を用いた。

拘束試験治具を Fig. 1 亿示与。この治具を用いた再 現処理で発生する熱間塑性変形量は, 加熱温度が $750^{\circ} \mathrm{C}$, $950^{\circ} \mathrm{C}, 1350^{\circ} \mathrm{C}$ の場合，それぞれ $0.6 \mathrm{~mm}, 0.7 \mathrm{~mm} 1.3$ $\mathrm{mm}$ となる。主た室温における拘束応力 $30 \sim 40 \mathrm{~kg} / \mathrm{mm}^{2}$ となる。

適用熱サイクルの最高加熱温度は， $600^{\circ} \mathrm{C}, 750^{\circ} \mathrm{C}$, $950^{\circ} \mathrm{C}, 1200^{\circ} \mathrm{C}, 1350^{\circ} \mathrm{C}$, とし, 冷却条件は，各鋼材に 刘する標準溶接条件に相当する泠却速度を適用した。 ま た二二重熱サイクル再現処理の場合には，先行憼サイク ル温度は $1350^{\circ} \mathrm{C}$ とし，後行熱サイクル温度奆变化させ た．後行熱サイクルは先行熱サイクル温度が $100^{\circ} \mathrm{C}$ 以 下よなってから付与した。

所定の熱サイクル再現処理を終了した後， $5 \times 10 \times 55$,

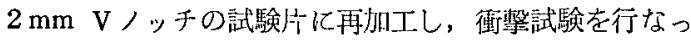
た。

\section{3. 実験結果}

实験結果の例を Fig. 2, Fig. 3 に示す. HT70, HT 80 の結果は，Fig. 3 亿示す HT 70 の結果之同一傾向を示 し，調質型高張力鋼は，同一の拘束効果を受けると考え られる、すなわち，調質型高張力鋼の場合，本実験程度 の哬束では，カタサや衝揧特性に影響をほとんよ゙およぼ さない。

一方, SM 50 では，単一熱サイクル㚮理の場合，拊 束の存在によりカタサの低下と衝擊特性の改善傾问が認 められる. しかし, 先行熱サイクルが存在し, 後行熱少 イクル温度が燒塺し過程に相当する温度領域となる場合 には，拘束の存在は，焼辰しによる衝整特性の回復を低 下させる傾问が認められる，後行熱サイクル温度が $\mathrm{A}_{3}$ 点以上亡なると, 单一熱サイクル好理時亡同㥞, カタサ
の低下と切久靯性の改湆が認められる。

以上を統括すると，調啠型高張力鋼（60キロ〜80キロ

)では，拘束の影響ははとんど認められなく，非調質型 鋼では，一般的には，力夕サの低下と切久欨性の改善が 期待出来る。しかし，多重熱サイクルを受ける場合に は、蓺サイクル形状により複雑な举動を示すと考元られ る。

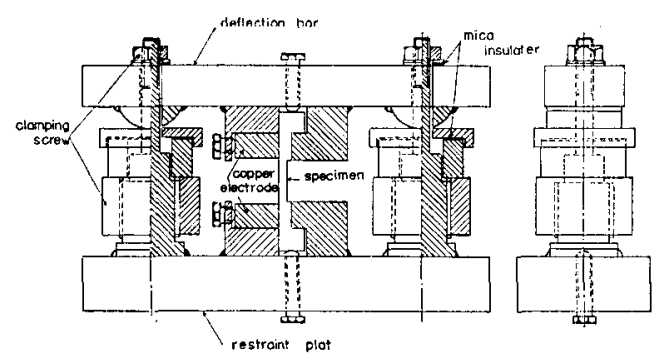

Fig. 1 Restraint device

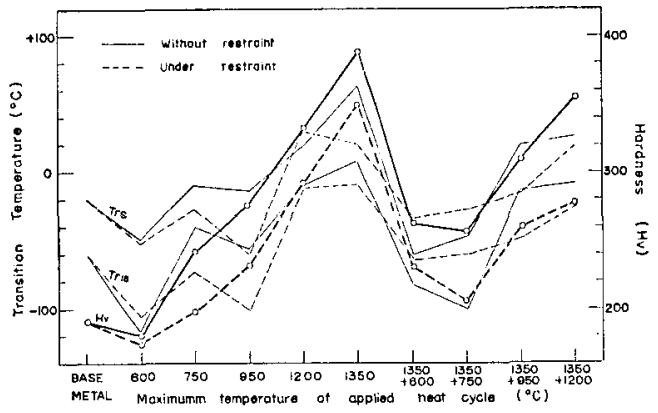

Fig. $2 \operatorname{Tr}_{S}, \operatorname{Tr}_{15}$ and $\mathrm{H}_{\mathrm{V}}$ of synthetic heat affected zone of SM 50

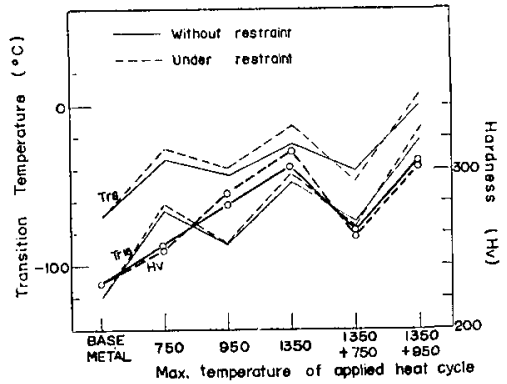

Fig. $3 \operatorname{Tr}_{\mathrm{S}}, \operatorname{Tr}_{15}$ and $\mathrm{H}_{\mathrm{V}}$ of synthetic heat affected zone of NK-HINT 70 


\title{
（29）低温用鋼材 YND-33 の溶接継手使用性能について
}

\author{
八幡製鉄侏八幡製鉄所 伊藤悌二 森山康十河泰雄 田中 潔
}

\section{1. 緒 言}

低温容器などに使用される低温用鋼材に対しては，そ の溶接部をも含めて優れた低温特性, 特に低温での船 性破壊非発生特性が要求される. 調質アルシャルド鋼 YND-33 溶接部の低温特性については一部既に報告して きたが，今回更に大型試験を中心に脆性破壊試験を実施 し，溶接継手の使用性能を再検討したので報告する。 著者らは各種鋼材に対する推奖溶接施工条件を求め, 溶接マニュアルの作成を遂行しつ〉砛，YND-33に

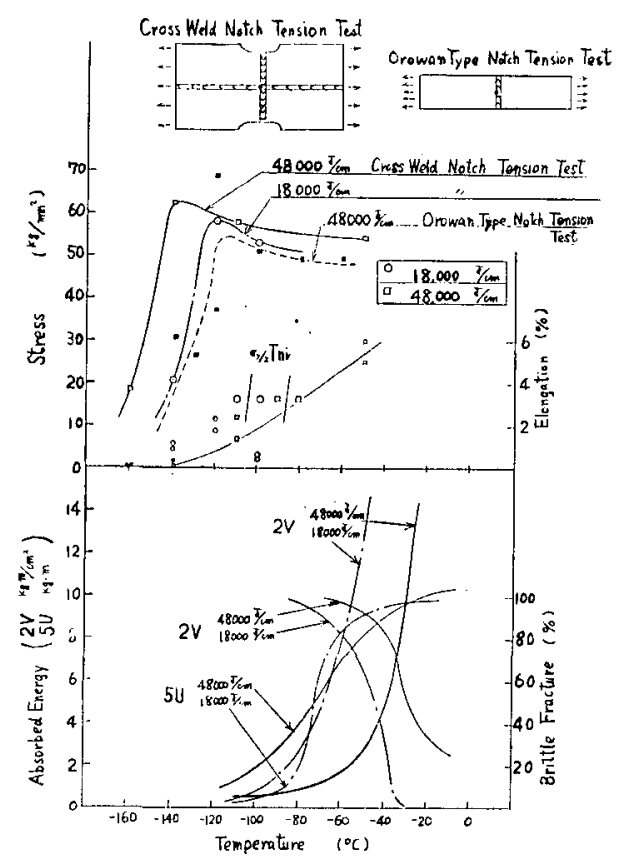

Fig. 1 Summary of various brittle fracture test for YND 33 welded joint
対しても木実験結果および促来のデータをもとにして被 㠅金属アーク溶接マニュアルを作成している。

\section{2. 実験方法}

Table 1 亿供試鋼の化学成分および機械的性質を示し た. 溶接は本実験では被覆金属アーク溶接のみを採用 し, 溶接条件を $18,000,35,000,48,000 \mathrm{~J} / \mathrm{cm}$ の 3 通りに 変化させた，溶接棒としては溶着鋼に対しても母材に匹 敵する諸性質を与えるために (5N-12（2.5\% Ni 系) 在 使用した。

\section{3. 実験結果}

Fig. 1 亿シャルピー試験と切欠引張試験の結果をまと めた。 叉 Table 2 に ESSO 試験子 Deep Notch 試験 の結果をまとめた。

特に冷涷型 L.P.C タンクなどのように静的応力下で 脆性破壞の非発生を与えればよいと思われるような溶接 構造物に対しては，Fig. 1 亿示した十字溶接切欠引張試 験や Deep Notch 試験の結果を考虑すれば良いと考元 られるので，てれらの結果より考察すると YND-33の 被覆金属アーク溶接継手では，入熱量の大小にか〉わら ず, 充分な低温度での対腕性破㯰強度を有していること がうかがえる，一方これらの大型試験結果とシャルピー 試験絬果の間には明確に説明できる相関はなく，又大型 試験の中でも切欠引張試験や Deep Notch 試験之衝撃 応力下でのキレッ発生を考える ESSO 試験との間にも 一定の関係は㒻られない。

上楛のような諸点を考慮して, YND-33 被覆金属アー ク溶接継手の施工条件を推奖した溶接マニュアルでも， 一般に採用される範囲での入熱量の制限は考えなくてよ いということにしている.

Table 1 Chemical composition and mechanical properties of tested steel

\begin{tabular}{c|c|c|c|c|c|c|c|c}
\hline $\begin{array}{c}\text { Plate } \\
\text { thickness }\end{array}$ & $\mathrm{C}$ & $\mathrm{Si}$ & $\mathrm{Mn}$ & $\mathrm{P}$ & $\mathrm{S}$ & $\begin{array}{c}\text { Y.P } \\
(\mathbf{k g / m m})\end{array}$ & $\begin{array}{c}\text { T.S } \\
(\mathbf{k g / m m} 2)\end{array}$ & $\begin{array}{c}\text { El. } \\
(\%)\end{array}$ \\
\hline $19 \mathrm{~mm}$ & 0.09 & 0.29 & 1.17 & 0.011 & 0.005 & 36.0 & 49.0 & 48.0 \\
\hline
\end{tabular}

Table 2 Results of ESSO test and deep notch test

\begin{tabular}{c|c|c|c}
\hline \multirow{2}{*}{$\begin{array}{c}\text { Heat input } \\
((\mathrm{J} / \mathrm{cm})\end{array}$} & ESSO test & \multicolumn{2}{|c}{ Deep notch test } \\
\cline { 2 - 4 } & $\sigma_{y / 2 T_{n i}\left({ }^{\circ} \mathrm{C}\right)}$ & $T_{N}\left({ }^{\circ} \mathrm{C}\right)$ & $\sigma_{y / 2 T_{i}(l=40)}\left({ }^{\circ} \mathrm{C}\right)$ \\
\hline 18,000 & -105 & -118 & -171 \\
48,000 & -85 & -92 & -204 \\
\hline
\end{tabular}




\section{（30）亜鉊メッキ鋼板の点溶接性について（第2報）}

（電気亚鉛メッキ鋸板の点溶接）

富士製鉄㑬中央研究所 小平一丸村泰三，田原建洋

\section{1. 緒言}

著者らは前報において溶融亚鉛メッキ法によって作ら れたスパングル鋼板と，これを熱好理によりスパングル を消したガルバニール鋼板の点溶接試験結果について報

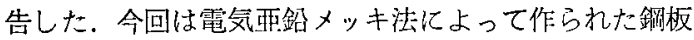
の点溶接について試験したのでその紏果を報告する.

\section{2. 試験方法}

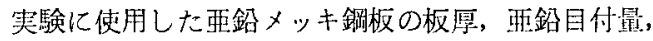
化学成分および機械们性質は Table 1 に示した通りて ある、実験方法は

1) 同じ板厚でメッキ層が両面とも同じ曆さのもの, メッキ厚さがそれぞれ異なるもの，および片面のみメッ キしたすのを組合せな場合。

2）板厚の異なるものを組合せた場合における点溶接

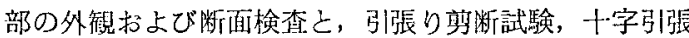
り試験，ならびに逨続打点試験に上る点溶接部の強度の 变化と電極の損賃度について調べて電気垔鉊メッ未鋼板 の点溶接性を検討した。

\section{3. 実験結果}

電気要鉊メッキ鋼板のメッキ層の厚さ $(2.0 \sim 7.6 \mu)$ は 溶融法によるメッキ愿さ $(13 \sim 43 \mu)$ の約留である。

今回は先ずメッキ層の厚さが 2.5 ミクロン以下の鉘板 について実験したがその結果の概要忺次の通りである。

1 ）電気亚鉊メッキ鋼板の点溶接条件は同板厚の軟鋼 板に比較して，溶接電流は10２0\%堌し，溶接時間は0 〜20\%増し，加圧力はほぶ同じでよい，(Fig. 1)

2）電気严鉛メッキ鋼板と同板厚の溶融亚鉊メッキ鋼 板の溶接条件を比較した場合，前者は溶接電流で10２0 \%減，溶接時間屯約10\%城とし，加生力はほぶ同じであ る. (Fig. 1)

3）西鉊メッキ厚さの異なったものを組合せた場合で
も溶接条件に差程変化はない。

4) 電気重鉊メッキ鋼板は亜鉛による電極チップの污 損が少なく，したがって同一電極チップをドレッシング せずに3500回以上の連続点溶接を行なっても点溶接部の 外倪ならびに性能は変らない（Fig. 2)

その他，板厚の異なった組合せの埸合の溶接条件とそ の性能，掼触抵抗の変化等についても述べる予管であ る.
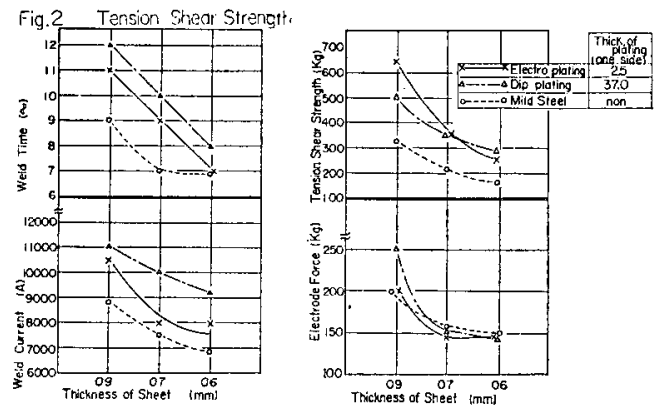

Fig. 1 Relation between welding conditions and thickness of $\mathrm{Zn}$ plated sheet

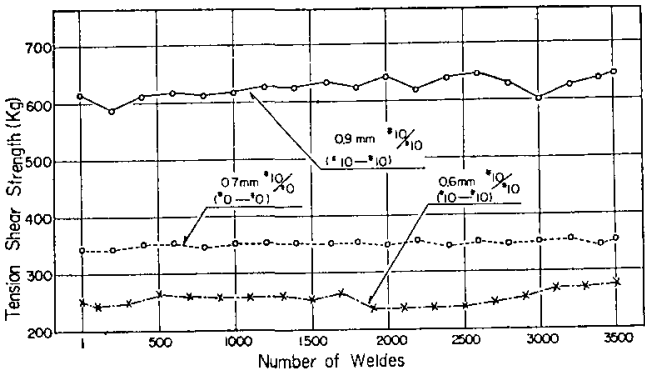

Fig. 2 Tension shear strength vs, numbe of welds

Table 1 Chemical compositions and mechanical properties of test sheet

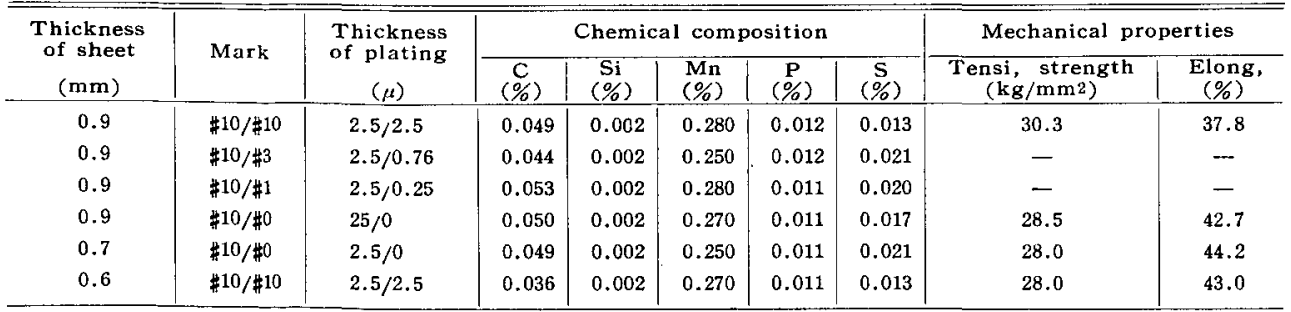




\section{（31）エレクトロガス溶接鋼の機械的性質におよぼすアルミニウムの影響}

\section{I 緒 言}

エレクトロガス溶接はエレクトロスラグ溶接と同様に 莝直逨続溶接で, 中板の溶接には能率的に利用されると 思われる.しかしエレクトロガス溶接の場合も, 溶融池 が大きく，溶融金属の凝固が遅いので，デンドライト組 織が大きく発達し，溶接鋼の切欠䩓性が一般に劣る。

本夷験では結晶粒微細化元素として特にアルミニウム を加えた $\mathrm{Si}-\mathrm{Mn}$ 系電極鋼線を試作し， $\mathrm{CO}_{2}-\mathrm{O}_{2}$ 被包力゙ スにより市販のエレクトロスラグ溶接機を用いて，エレ クトロガス溶接を行ない，得られた溶接鍋の機械的性質 および顕微鏡組織について調べた。

\section{II 実験方法および結果}

（i）まず予供实験として全自動 $\mathrm{CO}_{2}-\mathrm{O}_{2}$ アーク溶接 機の鋼線送給装置およびトーチ部分を利用し, 冷却銅板 を用いて Table 1 K示す電極鎡線 DS 1 および DS 60 で，板厚 $32 \mathrm{~mm}$ の軟鎆突合甘，エレクトロガス溶接し た。

エレクトロガス溶接中溶融池に種々の割合でアルミニ ウムを添加し，溶接銓のアルミニウム含量を变えた。そ して得られた溶接錐から V/ッチシャルピー衝撃試験片 を多数採取した。笑験結果を Fig. 1 に示す.

(ii) Fig. 1 の結果によりエレクトロガス溶接鋼への アルミニウム添加が衝撃值の收篦に效果があるととが倠 かめられたので, さらに各種のアルミニウムを含有した 銷線を試作し，市欺のエレクトロガス溶接装置により板 厚 $20 \mathrm{~mm}$ の軟銅をエレクトロガス溶接した。をして溶

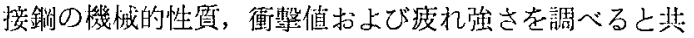
に顕微鏡観察，化学分析によりアルミニウムの効果につ いて検討を行なった。

本研究の結果, 溶接䥔中にアルミニウムを適当鼠添加 するとアルミニウム含有量の少ない溶接鍓にくらべて溶 接鍬の衝整值および疲れ強さが高くなるととを認めた。 しかしアルミニウムの添加晴が多すぎると衝撃值は著し く低下してくる。

$\begin{array}{lllll}\text { 名占屋大学工学部 } & \text { 益 } & \text { 水 } & \text { 功 } \\ \text { 名占屋大学大学院 } & \text { 今 } & \text { 非 洋 } & \text { 敬 }\end{array}$

とのアルミニウムによる欨性改善はマンガン，けい素 の他にモリブデンを含む溶接銅において特に顕著であっ た.

Table 1 Chemical analyses of electrode wires

\begin{tabular}{c|c|c|c|c|c|c|c}
\hline Elctrode wire & C & Si & Mn & P & S & Al & Mo \\
\hline DS 1 & 0.09 & 0.85 & 1.74 & 0.017 & 0.008 & - & - \\
DS 60 & 0.12 & 0.88 & 2.16 & 0.013 & 0.008 & - & 0.43 \\
A & 0.05 & 0.53 & 1.80 & 0.012 & 0.020 & 0.006 & - \\
B & 0.05 & 0.54 & 1.81 & 0.012 & 0.016 & 0.20 & - \\
C & 0.06 & 0.64 & 1.80 & 0.012 & 0.020 & 0.35 & - \\
D & 0.06 & 0.64 & 1.74 & 0.011 & 0.013 & 0.71 & - \\
E & 0.07 & 0.58 & 1.73 & 0.011 & 0.018 & 1.03 & - \\
F & 0.06 & 0.57 & 1.66 & 0.012 & 0.018 & 1.83 & - \\
\hline
\end{tabular}

Table 2 Chemical analyses of base metals

\begin{tabular}{c|c|c|c|c|c|c}
\hline Material & $\begin{array}{c}\text { Thickness, } \\
\mathrm{mm}\end{array}$ & $\mathrm{C}$ & $\mathrm{Si}$ & $\mathrm{Mn}$ & $\mathrm{P}$ & $\mathrm{S}$ \\
\hline $\mathrm{I}$ & 32 & 0.20 & 0.15 & 1.02 & 0.032 & 0.021 \\
$\Pi$ & 20 & 0.17 & 0.06 & 0.71 & 0.013 & 0.032 \\
\hline
\end{tabular}

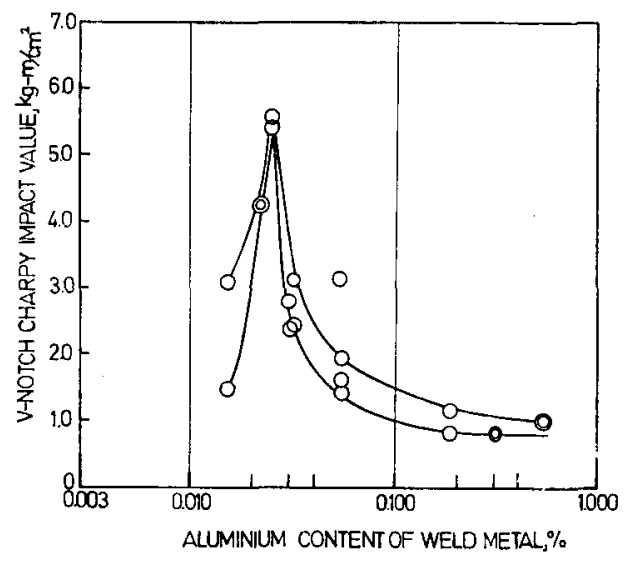

Fig. 1 Effect of aluminium content on impact ualue of electro-gas weld metal Remarks : test temperature, $0^{\circ} \mathrm{C}$, plate thickness, $32 \mathrm{~mm}$ 


\section{（32） ルート割れ発生機構に関する一実験}

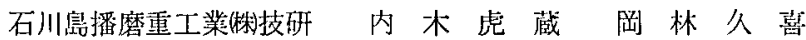

\section{1. 緒言}

溶接による冷間割れ几の発生機構を明らかにするために $\mathrm{y}$ 開先を有する鋼板に一層ビードをおき，冷却後ビード と直角方向に外力を負荷した時発生する割机について調 べた。

\section{2. 実験法および結果}

1）供試材：市販80キ口級高張力錹の結果について述べ る.

2 ）定荷重破壊試験扔よび予熱の效果：試験片の北状寸 法充 Fig. 1 亿示す。溶接後一定荷重老加壮た場合の破 塤応力一特間曲線学 Fig. 2 に示す。曲線工は予熱しな い場合，IIは $150^{\circ} \mathrm{C}$ の予熱を行なった場合の結果であ る.

3）時効の影響 : Fig. 3-A に示すでとく，溶接後外力 を負荷する前に時効を行なうと破墩強度は增加する。

4）応力時勃の影蠁：Fig. 3-B のごとく荷重をかけた 状態で保持すると破㜔強度は低下する。

5 ）歪時効の影響：Fig. 3-C のどとく溶接後荷重をか け，直ちに荷重を下げることによってルート部に予雨を 与え，時効を行なった場合破壊強度は增版する。たとえ ば切欠断面応力 $60 \mathrm{~kg} / \mathrm{mm}^{2}$ 与与， 2 時間常温時效を 行なった場合，その後の芫荷重試験の䋊果は Fig. 20 IIとなる。

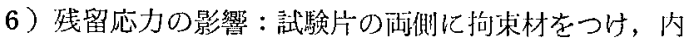
部応力を発址せしぬて試験した。乙の場合見掛の破壊溞 度は非常に低下した，た之えば予熱 $150^{\circ} \mathrm{C}$ ，残留応归約 $40 \mathrm{~kg} / \mathrm{mm}^{2}$ の試験片の定荷重割机試験の結果は Fig. 2 のIVのごとくになる。

\section{3. 検 討}

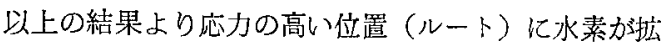
散し破壊強度を下げるものと考えられる、割れはルート より不連続的に発達するととが観祭された。したがって 各段階の割れ発生に対しエネルギー平衡論が適用できる あのと考えられる。すなわち

$$
E G=\sigma^{2}{ }^{2} w f(a / w)
$$

$\sigma_{g}$ は Gross stress, $E$ はヤング率, $f(a / w)$ は形状に よる係数， $w$ は板厚， $G$ は材料の特性值で, 水素の存在 する場合，応力時効によって低下する，残留応力と外力 は水素割れにおいても一次加算できるむの上判断され る.
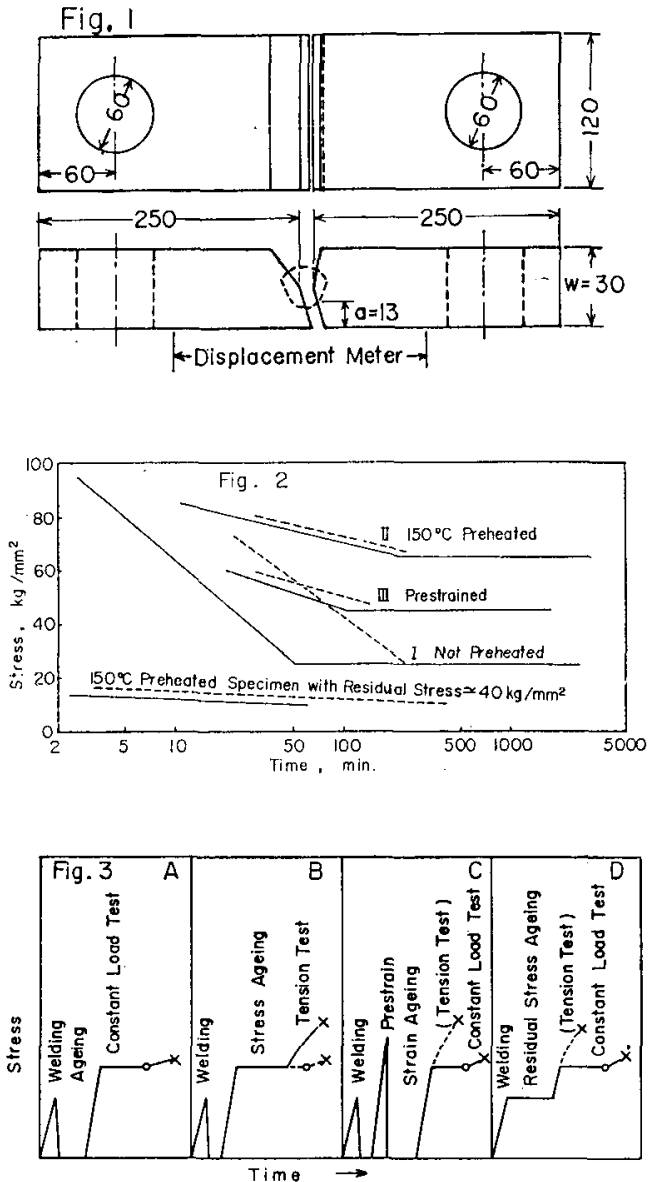